DOI 10. 18307/2018. 0517

(c) 2018 by Journal of Lake Sciences

\title{
鄱阳湖湿地典型植被群落地下水一土壤一植被一大气系统界面水分通 量及水源组成
}

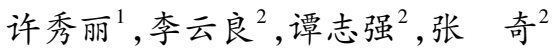 \\ ( 1 :太原理工大学水利科学与工程学院,太原 030024) \\ (2:中国科学院南京地理与湖泊研究所,中国科学院流域地理学重点实验室,南京 210008)
}

\begin{abstract}
摘 要: 地下水一土壤一植被一大气系统( GSPAC) 界面水分传输是湿地生态水文过程研究的关键. 本文选取鄱阳湖湿地高 位滩地的 2 种典型植被群落: 茵陈蒿( Artemisia capillaris) 和芦苇(Phragmites australis) 群落为研究对象, 运用 HYDRUS-1D 垂 向一维数值模拟, 量化了湿地 GSPAC 系统界面水分通量, 阐明了典型丰水年 (2012 年) 和枯水年 ( 2013 年) 鄱阳湖湿地植 被群落的蒸腾用水规律和水源组成. 结果表明: (1) 茵陈蒿和芦苇群落土壤一大气界面的年降水人渗量为 $1570 \sim 1600$ $\mathrm{mm}$, 主要集中在雨季 4-6月, 占年总量的 60\%; 植物一大气界面的年蒸腾总量分别为 $346 \sim 470 \mathrm{~mm}$ 和 $926 \sim 1057 \mathrm{~mm}$, 其 中 7-8 月植被生长旺季最大, 占年总量的 $40 \% \sim 46 \%$; 地下水一根区土壤界面的向上补给水量受不同水文年水位变化的 影响显著, 地下水年补给量分别为 $15 \sim 513 \mathrm{~mm}$ 和 $277 \sim 616 \mathrm{~mm}$, 主要发生在蒸散发作用强烈和地下水埋深较浅的时段. (2) 植被蒸腾用水分为生长初期 ( $4-6$ 月) 和生长旺季 $(7-10$ 月) 2 个阶段, 丰水年植被的整个生长期蒸腾用水充足, 枯 水年植被生长旺季的蒸腾用水受到严重水分胁迫, 实际蒸腾量仅为潜在蒸腾量的一半左右. (3) 不同水文年湿地植被生 长旺季的水源贡献不同: 丰水年茵陈蒿群落以地下水补给为主, 芦苇群落以湖水和地下水补给为主; 枯水年茵陈蒿群落 以降水和前期土壤水储量为主, 芦苇群落以地下水补给为主. 本研究结果有助于揭示湿地植被的水分利用策略, 为阐明 湖泊水情变化与植被演替的作用机理提供参考依据.
\end{abstract}

关键词: 水分通量;水源组成;植被水分胁迫;鄱阳湖湿地;HYDRUS-1D 模型;茵陈蒿;芦苇

\section{Water fluxes in the groundwater-soil-plant-atmosphere continuum and water sources of typical wetland vegetation communities in Poyang Lake}

\author{
XU Xiuli ${ }^{1}$, LI Yunliang ${ }^{2}$, TAN Zhiqiang ${ }^{2} \&$ ZHANG Qi ${ }^{2}$ \\ (1: College of Water Resources Science and Engineering, Taiyuan University of Technology, Taiyuan 030024, P.R.China) \\ (2: Key Laboratory of Watershed Geographic Sciences, Nanjing Institute of Geography and Limnology, Chinese Academy of \\ Sciences, Nanjing 210008, P.R.China)
}

Abstract: Water movement within the groundwater-soil-plant-atmosphere continuum (GSPAC) is the key to wetland eco-hydrologi-
cal process research. In this paper, two typical wetland vegetation communities, the Artemisia capillaris and Phragmites australis
communities were selected as study objects in Poyang Lake wetland. The HYDRUS-1D model was used to explore the GSPAC water
fluxes in the two wetland vegetation communities. Besides, the vegetation transpiration and water sources of the two typical vegeta-
tion communities were clarified and compared for high (2012) and low ( 2013 ) water table years. The results showed that: ( 1 )
The annual rainfall infiltration flux at soil-atmosphere interface amounted to $1570-1600 \mathrm{~mm}$, with $60 \%$ falling in the rainy season
from April to June. The annual transpiration at plant-atmosphere interface totalled $346-470 \mathrm{~mm}$ and $926-1057 \mathrm{~mm}$, respectively,
for the A. capillaris and $P$. australis communities, with the highest values from July to August taking up $40 \%-46 \%$ of the annual a-
mounts. The groundwater upward fluxes to rootzone were significantly influenced by the water table variation in different hydrological
years. The annual amounts of groundwater recharge were $15-513 \mathrm{~mm}$ and $277-616 \mathrm{~mm}$, respectively for the two vegetation commu-
nities, which concentrated in the periods with high water table and evapotranspiration rate. (2) The process of vegetation transpira-

* 国家自然科学基金项目 $(41601031,41771037,41401031)$ 和江苏省自然科学基金项目 (BK20141061) 联合资助. 2017-12-29 收稿;2018-03-06 收修改稿. 许秀丽(1987 ), 女,博士,讲师;E-mail:xlxu1987@ 163.com. 
tion were divided into two different stages: the initial (April-June) and the main (July-October) growth stage. In the high water table year, vegetation transpiration water used in the whole growth stage can be satisfied. In the low water table year, vegetation suffered severe water stress in the main growth stage, and the actual transpiration decreased to approximately half of the potential ones. (3) The supplying water sources of vegetation communities in main growth stage were different between the high and low water table years. In the high water table year, groundwater recharge was the major water source of the A. capillaris community, while groundwater and lake water were the major water sources of $P$. australis community. However, in the low water table year, rainfall infiltration and antecedent soil water storage become the major water sources of the A. capillaris community, and groundwater was the major water source of $P$. australis community. These results help to reveal the vegetation water utilization strategy and better understand the interaction mechanism of vegetation succession to hydrological changes in wetland.

Keywords: Water fluxes; supplying water sources; vegetation water stress; Poyang Lake wetland; HYDRUS-1D model; Artemisia capillaris; Phragmites australis

湿地生态系统以水循环过程为载体进行物质、能量以及信息交换,从而驱动湿地植被的生长、景观格局 变化和生态功能的实现 ${ }^{[1-2]}$. 地下水一土壤一植被一大气连续体 (GSPAC) 界面水文过程的研究是对湿地水文 循环理论的一种新的发展, 水分在土壤一大气、植物一大气、地下水一根区土壤底边界等界面的传输过程直接 制约着湿地生态系统的水量平衡 ${ }^{[3-4]}$. 但由于湿地生态环境复杂, 目前湿地水分传输的研究主要侧重土壤一 大气、植物一大气界面蒸散发通量的变化特征、影响因素与驱动机制 ${ }^{[5-7]}$,湿地地下水一根区土壤界面的水分 交换过程由于观测难度较大,相关研究还相对滞后. 事实上,根系、土壤一地下水界面是物质交换和能量传递 最为频繁、生物化学过程最活跃的一个区域 ${ }^{[8]}$, 特别是在季节性洪泛湿地, 水位波动使湿地在“陆生 (干)” 和“水生(湿)”生境间交替变化,地下水的向上补给和土壤水分的深层渗漏过程直接决定湿地生态系统的 水分动态, 影响植被蒸腾用水过程 ${ }^{[9-10]}$. 因此, 亟需从 GSPAC 系统的整体角度量化水循环在各界面的通量过 程, 深人完善对湿地系统复杂水分运移规律的认识, 增加对湿地植被生长水源组成和水分利用策略的理解.

鄱阳湖是我国最大的淡水湖泊,它承流域五河(赣江、抚河、信江、饶河、修水)来水,经调蓄后自湖口注 人长江, 水位的季节性升消变化形成近 $3000 \mathrm{~km}^{2}$ 干湿交替的湿地, 湿地植被沿高程梯度呈典型带状分布, 高 位滩地主要为中生性植物茵陈蒿 (Artemisia capillaris)、狗牙根 (Cynodon dactylon) 群落, 中高位滩地为挺水植 物芦苇 (Phragmites australis)、南荻 (Triarrhena lutarioriparia) 群落, 低位滩地为湿生植物苔草 (Carex cinerascens) 群落 ${ }^{[11-12]} .21$ 世纪以来, 长江中下游流域进人连续枯水年, 鄱阳湖枯水期水位连创新低,枯水时间提前 近半个月 ${ }^{[13-15]}$, 已有研究发现, 连续出现的低枯水位严重威胁湿地生态系统的稳定, 高位滩地植被出现中旱 生化、生产力降低、分布面积萎缩等一系列问题 ${ }^{[16-19]}$. 因此, 深人认识湿地植被群落 GSPAC 系统水循环过 程, 阐明不同水文年内湿地植被蒸腾用水规律和补给水源组成的差异, 是揭示湿地水文一植被作用机理的关 键, 能够为干旱状态下鄱阳湖湿地生态系统的保护提供科学参考.

目前, 鄱阳湖湿地生态水文过程的研究开展了大量工作, 主要集中在以下方面: (1) 基于流域尺度的水 文水动力过程和江湖作用关系研究 ${ }^{[15,20-21]}$; (2) 基于遥感手段的湿地植被景观格局与水情要素的关系研 究 ${ }^{[19,22]}$; (3) 基于采样调查的植被群落特征与水土环境因子的统计关系分析 ${ }^{[23-24]}$; (4) 基于控制实验的种群 生态指标对水深的响应研究 ${ }^{[25-26]}$. 虽然这些研究表明, 湖泊水位和地下水埋深是影响鄱阳湖湿地植被外在 特征 (如空间分布和生长特征) 的主控因子,但并未从植被水源组成的内在角度进一步解释湖泊水位变化对 植被的作用机理,而且近 $50 \mathrm{a}$ 来, 鄱阳湖经历了 1980s 和 1990s 的高水位期, 本世纪正处于水文干旱期 ${ }^{[14-15]}$, 分析低水位情景下湿地植被的水源补给, 对理解植被水分竞争和群落演替有重要意义. 近期, 林欢等 ${ }^{[27]}$ 对 鄱阳湖湿地芦苇群落出露时期的水分补排过程进行了初步分析, 然而, 该研究只采用了 1 年的水文数据, 对 翻阳湖由丰水年进人到枯水年,湿地植被蒸腾用水和水源组成可能发生的改变仍然缺乏全面理解.

数学模型是定量研究湿地水分运移的重要手段之一, HYDRUS-1D 是由美国农业部盐碱土实验室 (U.S. Salinity Laboratory) 于 1998 年开发的一款用来研究饱和一非饱和孔隙水流动和物质传输的模型 ${ }^{[28]}$, 因其良 好的适用性被广泛应用于农田生态系统和河流湿地系统 ${ }^{[10,29]}$. 本文采用 HYDRUS-1D 水分运移模块, 针对 鄱阳湖湿地中高位滩地的 2 种植被群落: 茵陈蒿和芦苇群落, 分别构建了非饱和一维垂向水分运移模型, 从 界面水文的角度量化 GSPAC 系统的水分通量, 揭示典型丰水年 (2012 年) 和枯水年 (2013 年) 条件下, 湿地 
补给水源贡献及其对植被蒸腾耗水的影响. 研究结果可为水文条件变化与湿地植被演替和恢复的作用机制 研究提供理论参考.

\section{1 材料和方法}

\section{1 试验区概况}

鄱阳湖湿地位于江西省北部,多年平均降水量在 $1400 \mathrm{~mm}$ 以上, 主要集中在 $4-6$ 月, 约占全年总雨量 的 $47 \%$; 多年平均水面蒸发量 $1080 \mathrm{~mm}, 7-10$ 月 (伏旱期) 蒸发最强 ${ }^{[12,30]}$. 洲滩湿地是鄱阳湖最主要的湿地 类型, 占天然湿地总面积的 $60 \%$ 以上, 主要分布于流域五大河人湖三角洲处, 包括赣江南支与抚河交汇处的 冲积湿地、赣江主支与修河交汇处的冲积湿地和饶河河口湿地 (图 1a), 其中分布面积最大、发育最为典型的 是鄱阳湖最大的人湖河流赣江主支与修河下游河湖交汇处的复合三角洲湿地 ${ }^{[31-33]}$. 本文选取的洲滩湿地断 面即位于赣江主支与修河交汇处 $\left(29^{\circ} 14^{\prime} 34^{\prime \prime} \mathrm{N}, 116^{\circ} 00^{\prime} 11^{\prime \prime} \mathrm{E}\right)$, 是典型的人湖冲积三角洲前缘湿地, 且在 1998 年被划归为江西省鄱阳湖吴城国家自然保护区, 适宜进行长期定点观测, 能够反映自然状态下鄱阳湖洲滩 湿地的生态水文特征.

试验区长约 $1.2 \mathrm{~km}$, 地形由赣江一侧堤岸向主湖区逐渐倾斜, 高程差近 $6 \mathrm{~m}$, 地形坡度 $0.2 \% \sim 2.0 \%$ (图 $1 \mathrm{~b})$. 年内水位季节性波动显著, 地下水位埋深变化范围为 $0 \sim 10 \mathrm{~m}$, 最低地下水位出现在 1 月份, 最高地下 水位出现在 7-8 月份, 5 月下旬鄱阳湖水位上涨,湿地低位滩地受淹, 8 月之后湖泊水位消退, 洲滩出露. 季 节性干湿交替发育了典型的洲滩湿地植被, 沿着高程和土壤水分梯度茵陈蒿、芦苇和灰化蕚草群落呈带状 分布, 分界明显(图 1b), 且涵盖了中生性草甸、挺水植被、湿生植被等鄱阳湖洲滩的主要植被类型. 茵陈蒿 群落分布于高位滩地 17 18 m 范围内, 很少被水淹; 芦苇群落位于中高位滩地 $15 \sim 17 \mathrm{~m}$ 范围内, 丰水年 78 月淹水 $1 \sim 2$ 月左右. 采样调查显示, 两群落植物生长过程均为单峰型, 3 月开始萌发, $4-6$ 月为春季缓慢 生长期, 7- 10 月为夏秋生长旺季, 12 月以后逐渐枯萎, 覆盖度分别为 $60 \%$ 和 $90 \%$ 以上, 长势良好 ${ }^{[23]}$. 综上 所述, 本文选取的湿地断面综合考虑了地理位置、地形变化、水文特征、土壤性质、植被类型和分布格局等多 个方面,能够为鄱阳湖洲滩湿地生态水文过程研究提供代表性的实验数据和物理模型.
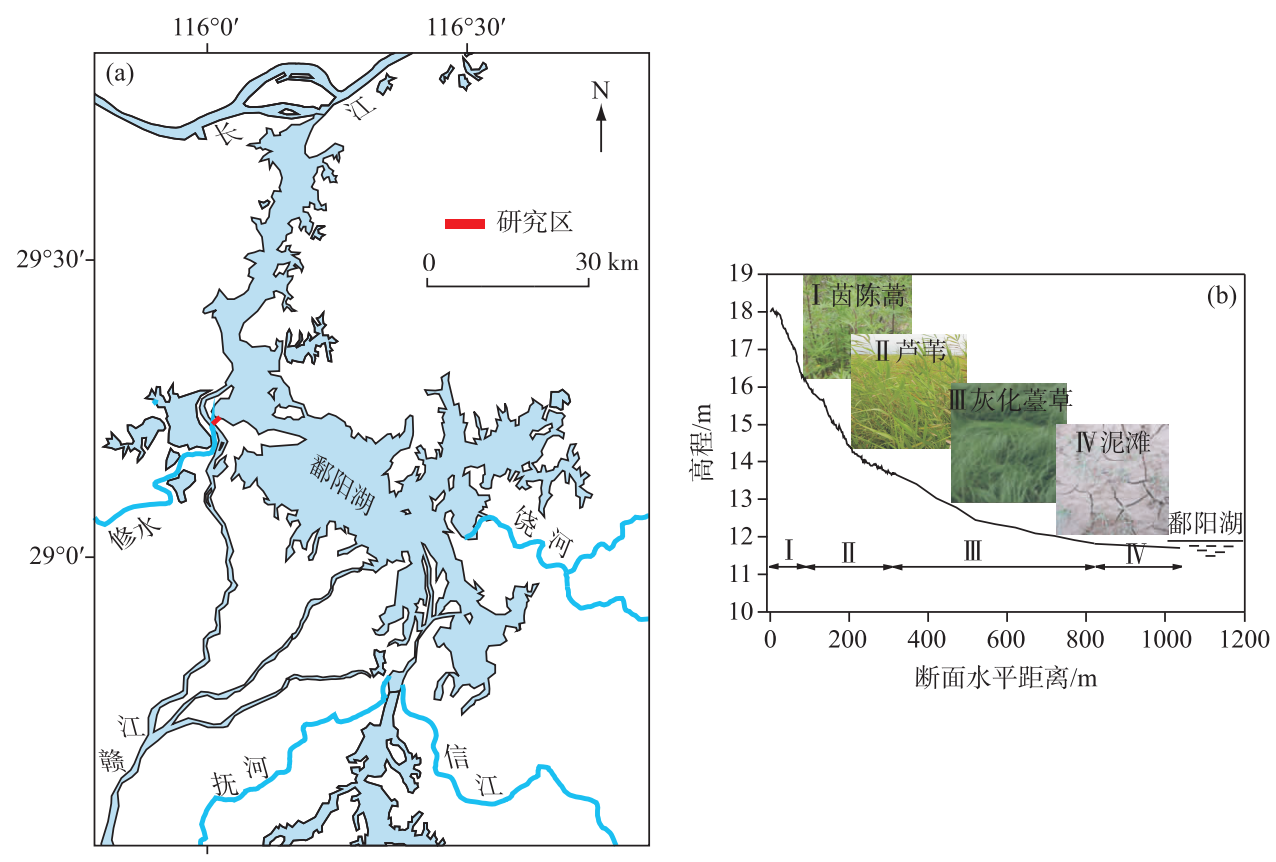

图 1 研究区位置 (a) 和洲滩湿地断面 (b)

Fig.1 Location of study area in Poyang Lake (a) and the schematic diagram of the delta wetland transect (b) 


\section{2 数据获取}

2011 年在试验区不同植被群落分别布设了地下水位观测井、土壤含水度观测探头 (地面以下 $10 、 50$ 、 $100 \mathrm{~cm}$ )、气象观测系统和波文比观测系统, 数据均自动采集, 详细的监测信息可参见文献 [34]. 此外, 同步 开展了地形测量、不同植被群落月度样方调查等; 同时对研究区断面土壤质地进行了采样分析, 利用激光粒 度仪测定了土壤的颗粒分布 ${ }^{[35]}$; 且在 2013 年 8 月植被根系发育基本成熟时期按 $10 \mathrm{~cm} \times 10 \mathrm{~cm} \times 10 \mathrm{~cm}$ 分层 采集 $0 \sim 100 \mathrm{~cm}$ 深土壤内的植被根系, 利用根系扫描仪测定了植被根系长度, 为数值模型的构建提供数据 支撑.

\section{3 典型年选择}

收集离研究区最近的鄱阳湖星子水文站 1955-2013 年的湖泊水位数据, 基于年平均水位进行频率分 析, 计算得到丰水年 $P=25 \%$ 和枯水年 $P=75 \%$ 所对应的年平均水位分别为 13.85 和 $12.63 \mathrm{~m}$. 根据 2012 年和 2013 年的实测水位数据计算可知, 2012 年年平均水位为 $14.02 \mathrm{~m}$,与丰水年设计水位值接近, 2013 年年平均 水位为 $12.17 \mathrm{~m}$, 低于枯水年设计水位值, 所以, 本文将 2012 看作丰水年, 2013 年看作枯水年, 探究不同水文 年条件下湿地水分的界面传输过程.

\section{2 典型湿地植被群落 GSPAC 系统水分垂向运移模型的构建}

\section{1 模型概化}

试验区地面坡降小于 $2 \%$, 且土壤主要为砂土和粉砂土, 不存在粘性土夹层 ${ }^{[35]}$, 所以水分垂向渗透性强, 壤中流可基本忽略. 同时, 地下水水平水力坡度小于 0.002 , 饱水带侧向径流微弱, 因此, 模型主要考虑典型 植被群落 GSPAC 系统垂向一维的水分交换. 根据试验区不同植被群落水文条件的季节变化, 可将研究区分 为洲滩出露和洲滩淹水 2 种情景, 茵陈蒿群落地表全年出露, 出露时期根区垂向一维水量平衡示意图如图 2a 所示; 芦苇群落年内季节性淹水, 淹水时期水量平衡模型示意图如图 $2 \mathrm{~b}$ 所示, 出露时期水量平衡关系与 茵陈蒿群落一致.
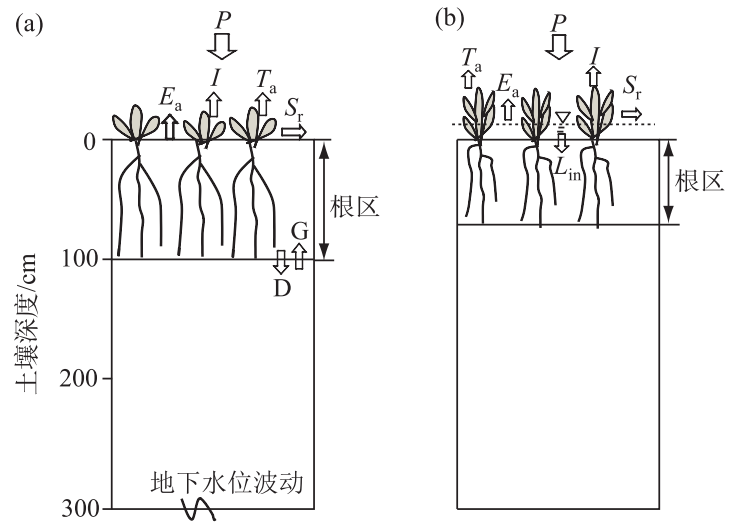

图 2 茵陈蒿群落出露 (a) 和芦苇群落地表淹水 $(\mathrm{b})$ 情况下垂向一维水量平衡示意图

Fig.2 Diagram of one-dimension vertical water balance when the A. capillaris community was exposed (a) and the P. australis community was flooded (b)

洲滩湿地出露期,地表与大气接触, 根系区土壤水量平衡关系可表示为:

$$
\left(P-I-S_{\mathrm{r}}\right)+G-D-E_{\mathrm{a}}-T_{\mathrm{a}}=\Delta W
$$

式中, $P$ 为降水量 $(\mathrm{mm}) ; I$ 为植被截留量 $(\mathrm{mm}) ; S_{\mathrm{r}}$ 为地表产流量 $(\mathrm{mm}) ; G$ 为地下水向上对根系区的补给量 $(\mathrm{mm}) ; D$ 为土壤水的深层渗漏量 $(\mathrm{mm}) ; E_{\mathrm{a}}$ 为土壤/水面蒸发量 $(\mathrm{mm}) ; T_{\mathrm{a}}$ 为植被蒸腾量 $(\mathrm{mm}) ; \Delta W$ 为根区土 壤水储量变化量 $(\mathrm{mm})$.

洲滩湿地淹水期, 地面被湖水覆盖, 地下水出露地表, 整个土体处于饱和状态 $(\Delta W \approx 0)$, 根系区土壤底 边界上下水势差为零, 无向上人渗补给和向下渗漏量 $(G=D \approx 0)$, 降水扣除植被截留量后可视为全部转换为 
地表径流量 $\left(P-I-S_{\mathrm{r}}=0\right)$, 此时, 蒸散发消耗水量全部来自湖水,则水分补排关系可简化为:

$$
L_{\text {in }}=E_{\mathrm{a}}+T_{\mathrm{a}}
$$

式中, $L_{\text {in }}$ 为湖水补给量 $(\mathrm{mm})$; 其余变量同上.

\section{2 数学模型的构建}

2.2.1 模型原理与数学描述 变饱和介质中土壤垂向水流运动使用一维 Richards 方程描述 ${ }^{[28]}$ :

$$
\frac{\partial \theta}{\partial t}=\frac{\partial}{\partial z}\left[K(\theta)\left(\frac{\partial h}{\partial z}+1\right)\right]-S(z, t)
$$

式中, $\theta$ 为土壤体积含水量 $\left(\mathrm{cm}^{3} / \mathrm{cm}^{3}\right) ; h$ 为土壤负压 $(\mathrm{cm}) ; t$ 为时间 $(\mathrm{d}) ; K(\theta)$ 为非饱和渗透系数 $(\mathrm{cm} / \mathrm{d}) ; z$ 为垂直方向土壤深度 $(\mathrm{cm}) ; S(z, t)$ 为根系吸水速率 $\left(\mathrm{cm}^{3} /\left(\mathrm{cm}^{3} \cdot \mathrm{d}\right)\right)$, 采用 Feddes 模型 ${ }^{[36]}$ :

$$
S(z, t)=\alpha(h) \cdot r(z) \cdot T_{\mathrm{p}}
$$

式中, $T_{\mathrm{p}}$ 为潜在蒸腾率 $(\mathrm{cm} / \mathrm{d}) ; r(z)$ 为根系吸水分布函数 $\left(\mathrm{cm}^{-1}\right) ; \alpha(h)$ 为水分胁迫函数 $(0 \leqslant \alpha \leqslant 1)$, 反映了 由于土壤水分亏缺而导致的植被根系吸水速率的减少, 采用 S-Shaped 模型描述 ${ }^{[37]}$ :

$$
\alpha(h)=\frac{1}{1+\left(h / h_{50}\right)^{p}}
$$

式中, $h_{50}$ 为潜在蒸腾速率下降一半时土壤的负压 $(\mathrm{cm}) ; p$ 为常数, 用来描述蒸腾速率随负压增加的下降 坡度.

潜在蒸散发 $\left(E T_{\mathrm{p}}\right)$ 利用实测气象资料和植被叶面积指数, 根据联合国粮食与农业组织 $(\mathrm{FAO})$ 推荐的 Penman-Monteith 方程确定 ${ }^{[38]}$, 并根据 Beer's 公式利用 $L A I$ 进一步分割为潜在植物蒸腾 $\left(T_{\mathrm{p}}\right)$ 和潜在土壤蒸发 $\left(E_{\mathrm{p}}\right)^{[39]} . T_{\mathrm{a}}$ 与 $T_{\mathrm{p}}$ 的比值 $\left(T_{\mathrm{a}} / T_{\mathrm{p}}\right)$ 被定义为水分胁迫指数 ${ }^{[40]}$, 无量纲, 变化范围为 $0 \sim 1$, 其值越小说明植被生 长受到的水分胁迫越大, 缺水越严重. $E_{\mathrm{a}}$ 由模型根据土壤表面含水量变化确定, 忽略土壤水分垂直分布情 况, 绝大多数情况下, 表层土壤负压水头高于临界值, $E_{\mathrm{a}}=E_{\mathrm{p}}$, 当土壤表面负压水头低于临界值时, $E_{\mathrm{a}}<E_{\mathrm{p}}$, 临 界值取地表最小压力水头的绝对值为 $10^{-6} \mathrm{~cm}^{[28]}$.

2.2.2 边界条件和初始条件 模型上边界选在地表, 洲滩出露时期, 上边界条件给定为通量边界, 接受降水补 给和蒸散发消耗 (图 3a) ; 地面淹水时期, 给定为水头边界. 确切而言, 模型上边界条件的给定视水情变化而 定, 茵陈高群落因其全年呈出露状态, 所以整个模拟期内均给定为通量边界, 而季节性淹水的芦苇群落给定 为变通量/水头边界条件, 根据监测点水位变化确定洲滩出露和洲滩淹水的时间段,分别赋予模型控制参数 KodTop $=-1$ 或 1 , 模型通过判断 KodTop 取值实现通量边界和水头边界条件间的自动转换, 即洲滩出露时为 通量边界、淹水时为水头边界.

模型下边界选在各植被群落模拟期内最低地下水位处, 即茵陈蒿和芦苇群落地面以下的 10 和 $8 \mathrm{~m}$, 给 定为压力水头边界 (图 3b), 以此模拟地下水位季节波动条件下湿地土壤水分的动态变化.

模型初始条件为 2012 年 1 月 1 日土壤含水率的垂向分布.
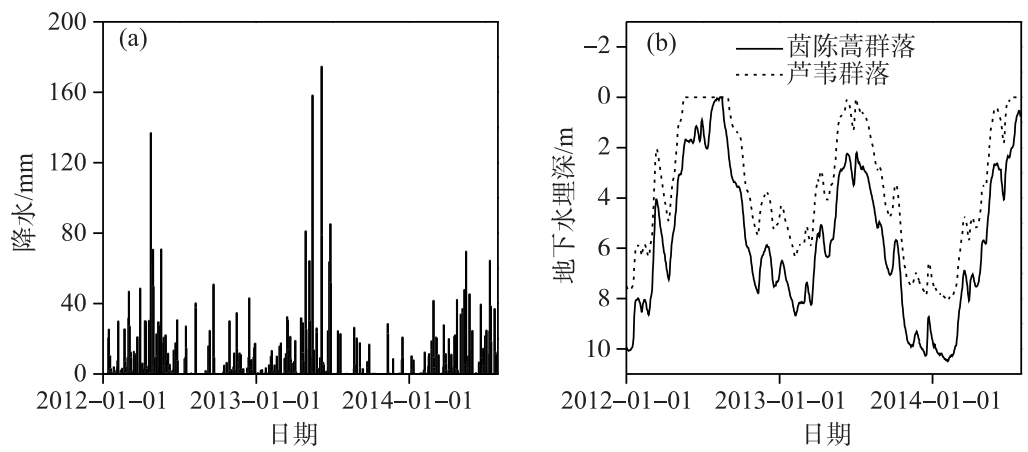

图 3 降水 $(a)$ 和地下水埋深 $(b)$ 的日变化

Fig.3 Daily variation of precipitation (a) and the groundwater level depth (b) 
2.2.3 土层划分 依据野外采样调查所获的土壤质地测试结果,研究区土壤属性存在明显垂向异质性(表 1), 土壤异质性以及水分特征曲线参数的差异将会对水分运移产生影响, 因此模型将各群落土壤剖面划分 为不同的土壤属性层. 茵陈蒿群落划分为 4 层, 芦苇群划分为 3 层, 不同土壤层赋予不同的土壤动力学参数.

表 1 茵陈蒿和芦苇群落土壤机械组成和容重

Tab.1 Measured soil texture composition and bulk density data in A. capillaris and P. australis communities

\begin{tabular}{|c|c|c|c|c|c|c|c|}
\hline 土壤分层 & & 土壤深度/ $\mathrm{cm}$ & 砂/\% & 粉砂/\% & 黍土 $/ \%$ & 干容重/ $\left(\mathrm{g} / \mathrm{cm}^{3}\right)$ & 土壤质地 \\
\hline \multirow[t]{4}{*}{ 茵陈蒿群落 } & 1 & $0 \sim 20$ & 92.8 & 6.2 & 1.0 & 1.33 & 砂土 \\
\hline & 2 & $20 \sim 80$ & 91.2 & 7.8 & 1.0 & 1.26 & \\
\hline & 3 & $80 \sim 120$ & 84.2 & 9.6 & 6.2 & 1.35 & \\
\hline & 4 & $120 \sim 1000$ & 54.2 & 36.4 & 10.4 & 1.37 & 粉砂土 \\
\hline \multirow[t]{3}{*}{ 芦苇群落 } & 5 & $0 \sim 20$ & 13.6 & 76.0 & 11.4 & 1.35 & 粉砂土 \\
\hline & 6 & $20 \sim 80$ & 23.1 & 64.3 & 12.5 & 1.24 & \\
\hline & 7 & $80 \sim 800$ & 17.7 & 68.4 & 13.9 & 1.40 & \\
\hline
\end{tabular}

2.2.4 输入数据 上边界的降水量和下边界的地下水压力水头数据均通过自动监测系统获取 (图 3), 上边界 的潜在蒸散发量根据风速、太阳辐射、最高气温、最低气温、平均湿度、日照时数等气象数据和叶面积指数 $(L A I) 、$ 平均株高等植物生长数据(图 4) 计算后输人.

植被根系吸水数据包括根系层深度和吸水密度函数, 用来描述根系吸水速率在土壤剖面上的垂向分 布, 茵陈蒿和芦苇群落的根系层深度分别为 100 和 $80 \mathrm{~cm}$, 总根长 $L_{\mathrm{R}}$ 代表整个根系层土壤内直径小于 $2 \mathrm{~mm}$ 的毛细吸水根的总长度, 分别为 3222 和 $6217 \mathrm{~cm}$, 分段函数描述如下:

$$
\left.r(z)\right|_{\text {菌除蓠 }}=\left\{\left.\begin{array}{cc}
82.2 / L_{\mathrm{R}} & 0 \leqslant z \leqslant 20 \mathrm{~cm} \\
26.6 / L_{\mathrm{R}} & 20<z \leqslant 60 \mathrm{~cm} \\
12.9 / L_{\mathrm{R}} & 60<z \leqslant 100 \mathrm{~cm}
\end{array} \quad r(z)\right|_{\text {芦蒂 }}=\left\{\begin{array}{cc}
317 / L_{\mathrm{R}} & 0 \leqslant z \leqslant 10 \mathrm{~cm} \\
85 / L_{\mathrm{R}} & 10<z \leqslant 40 \mathrm{~cm} \\
12.4 / L_{\mathrm{R}} & 40<z \leqslant 80 \mathrm{~cm}
\end{array}\right.\right.
$$

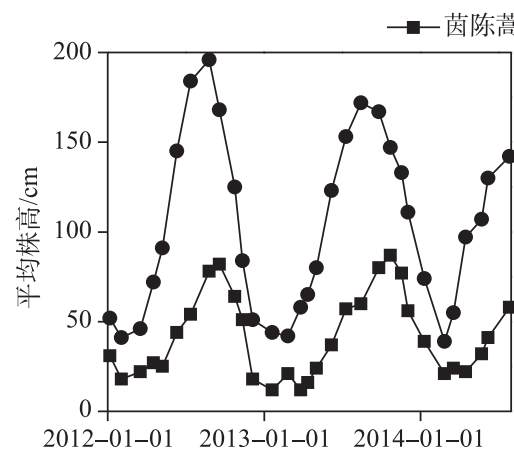

日期

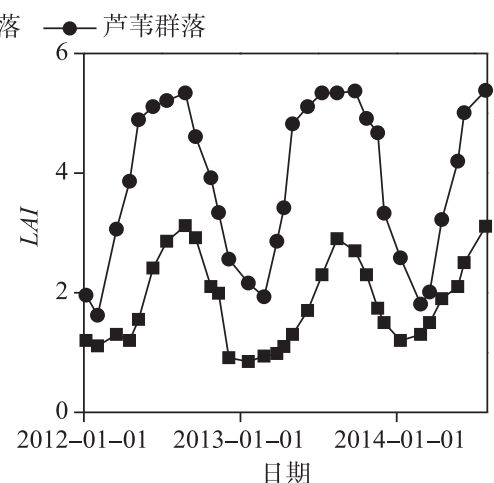

日期

图 4 茵陈蒿和芦苇群落的平均株高和叶面积指数变化

Fig.4 Variation of average height and the leaf area index of $A$. capillaris and $P$. australis communities

2.2.5 模型参数化 土壤水分特征曲线参数有残余含水量 $\theta_{\mathrm{r}}$ 、饱和含水量 $\theta_{\mathrm{s}}$ 、经验参数 $\alpha$ 和 $n$, 通过土壤脱湿 实验中获取的土壤负压和含水率的观测数据, 利用最小二乘法来拟合 van-Genuchten 模型获取 (图 5); 饱和 渗透系数 $(K s)$ 的初始值根据室内渗透实验测定结果赋予, 同时采用土壤机械组成利用 HYDRUS-1D 自带的 人工神经网络模型推算可能的参数取值, 两者结合确定参数率定过程中渗透系数的取值范围为 $38 \sim 554$ $\mathrm{cm} / \mathrm{d}$.

水分胁迫方程参数 $h_{50}$ 和 $p$ 的参数取值与土壤质地和植被类型有关, 依据已有文献报道 $h_{50}$ 和 $p$ 的变化范 围分别为 $-950 \sim-5000 \mathrm{~cm}$ 和 $1.5 \sim 3.0^{[36,41]}$. 茵陈蒿群落的土壤质地主要为粗颗粒的砂土, 水分特征曲线显示土 

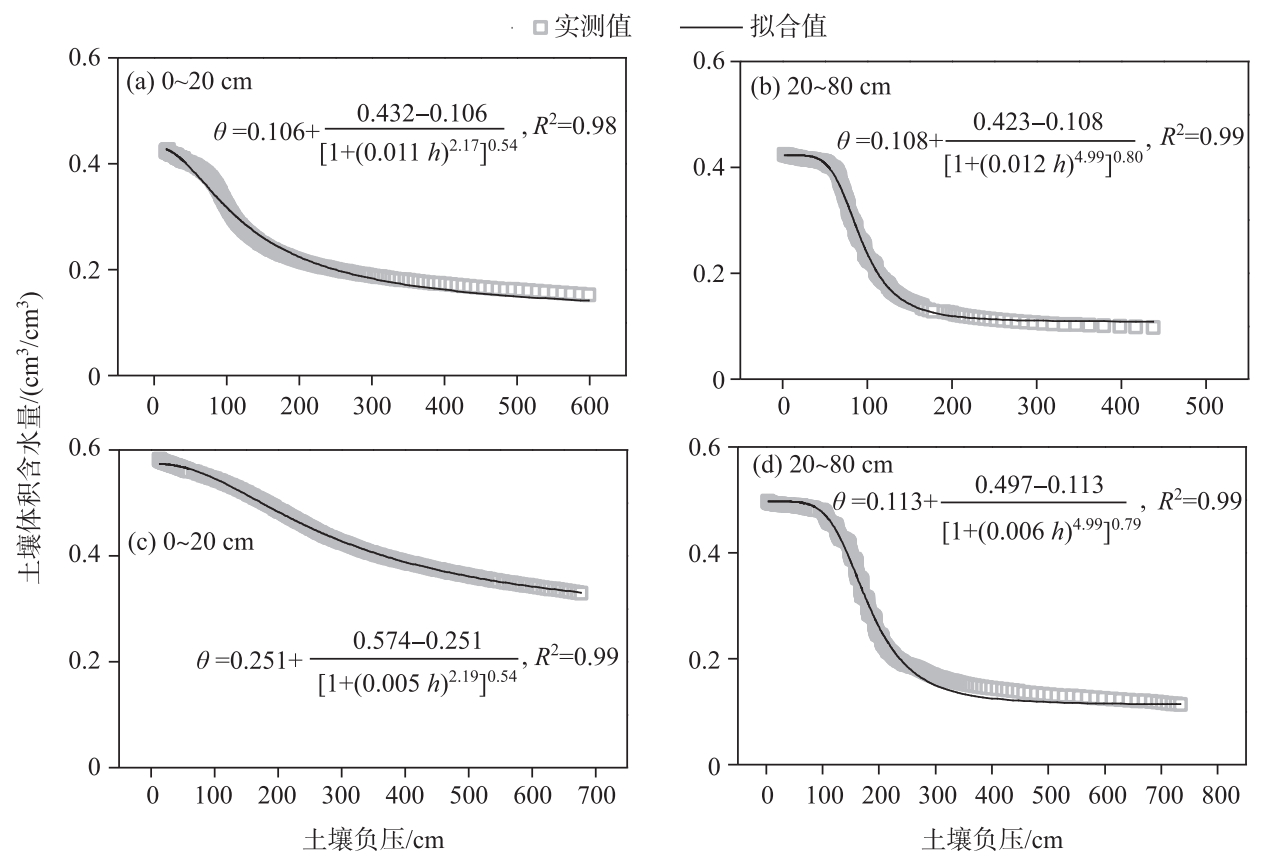

图 5 脱湿条件下茵陈蒿 $(\mathrm{a} 、 \mathrm{~b})$ 和芦苇 $(\mathrm{c} 、 \mathrm{~d})$ 群落土壤水分特征曲线 Van-Genuchten 模型拟合结果

Fig.5 Van-Genuchten model of water retention curves for A. capillaris ( a,b) and P. australis (c,d) communities

壤含水量在负压高于 $300 \mathrm{~cm}$ 以后即迅速降低至 $10 \%$ 左右, 说明土壤水分的疏干过程线较陡, 因此, $h_{50}$ 和 $p$ 分 别被赋予较大的参数取值 $-950 \mathrm{~cm}$ 和 3 , 以此代表迅速的土壤脱湿过程. 而芦苇群落土壤质地主要为粉砂土, 参考 Xie 等 ${ }^{[10]}$ 在黄河三角洲细砂土芦苇湿地的研究结果, $h_{50}$ 和 $p$ 的初始值分别被赋予 $-2456 \mathrm{~cm}$ 和 3 .

\section{3 模型率定}

模型整个模拟时段为 2012 年 1 月 1 日 -2014 年 7 月 30 日,率定期为 2012 年 1 月 1 日 -2013 年 5 月 31 日,验证期为 2013 年 6 月 1 日 - 2014 年 7 月 30 日. 利用实测的 10、50、100 cm 处的土壤含水量数据,采用 Marquardt-Levenberg 反演法对初始土壤参数进一步率定. 参数敏感性分析结果显示, 土壤水分动态对参数 $h_{50}$ 和 $p$ 不敏感,因此本文不再对 $h_{50}$ 和 $p$ 进行率定.

\section{3 结果分析}

\section{1 模型率定与验证结果}

本文率定后的土壤参数取值见表 2 , 茵陈蒿群落上层为砂土, 下层为粉砂土, $K s$ 取值为 $75 \sim 277 \mathrm{~cm} / \mathrm{d}$, 芦 苇群落为粉砂土, $K s$ 为 $45 \sim 102 \mathrm{~cm} / \mathrm{d}$, 渗透系数与美国农业部给出的相应土质参数参考范围基本一致 ${ }^{[42]} \cdot \theta_{\mathrm{r}}$ 取值为 $0.03 \sim 0.04 \mathrm{~cm}^{3} / \mathrm{cm}^{3}$, 与砂类土壤的调萎系数比较接近 ${ }^{[43]}$, 比土壤水分特征曲线模型拟合获取的 $\theta_{\mathrm{r}}$ 值 偏低, 主要原因是受实验条件限制, 脱湿实验只测定了低吸力条件下的土壤负压 $(0 \sim 700 \mathrm{~cm})$, 缺乏高吸力条 件下的实测数据点, 土壤含水率可能尚没有降低至一个恒定值, 但本文 $\theta_{\mathrm{r}}$ 取值与美国农业部粉砂土和砂土 $\theta_{\mathrm{r}}$ 的参考范围 $0.034 \sim 0.045 \mathrm{~cm}^{3} / \mathrm{cm}^{3}$ 基本吻合, 其他参数也在合理范围内 ${ }^{[42]}$.

整体来看, 不同植被群落土壤含水量模拟值与实测值变化趋势一致 (图 6), 土壤含水量的模拟值既能体 现对降水和地下水位上升补给的响应, 也能再现雨后和退水后土壤的疏干过程, 能够反映湿地土壤的季节 性干湿交替变化. 然而, 茵陈蒿群落 2012 年初期土壤含水量模拟值对降水的响应非常敏感, 实测值却变化 很小, 这可能与仪器安装初期不稳定有关, 另外, 在个别降水时段和土壤含水量达到饱和后的快速下降过 程, 模拟值与实测值的偏差较大 (图 6a), 这主要是因为模型对降水的响应和土壤水分的衰减非常敏感, 无法 考虑地表枯枝落叶层对降水的滞留作用和对土壤水分损失的减缓作用. 采用定量指标评价模拟精度, 茵陈 
蒿群落率定期和验证期均方根误差 $R M S E$ 的变化范围为 $0.03 \sim 0.07 \mathrm{~cm}^{3} / \mathrm{cm}^{3}$, 决定系数 $R^{2}$ 为 $0.72 \sim 0.92$; 芦 苇群落 $R M S E$ 为 $0.02 \sim 0.04 \mathrm{~cm}^{3} / \mathrm{cm}^{3}, R^{2}$ 的变化范围为 $0.66 \sim 0.85$ (表 3), 统计指标表明, 本文构建的水分运 移模型的模拟精度较好, 可以用于不同植被群落垂向界面水分运移规律分析.

表 2 模型率定后的土壤水分特征曲线参数取值

Tab.2 Calibrated soil hydraulic parameters

\begin{tabular}{ccccccc}
\hline 植被群落 & 土壤深度 $/ \mathrm{cm}$ & $\theta_{\mathrm{r}} /\left(\mathrm{cm}^{3} / \mathrm{cm}^{3}\right)$ & $\theta_{\mathrm{s}} /\left(\mathrm{cm}^{3} / \mathrm{cm}^{3}\right)$ & $\alpha / \mathrm{cm}^{-1}$ & $n$ & $K s /(\mathrm{cm} / \mathrm{d})$ \\
\hline 茵陈蒿群落 & $0 \sim 20$ & 0.04 & 0.47 & 0.031 & 2.31 & 277 \\
& $20 \sim 80$ & 0.03 & 0.49 & 0.036 & 2.11 & 248 \\
& $80 \sim 120$ & 0.03 & 0.48 & 0.008 & 3.46 & 183 \\
& $120 \sim 1000$ & 0.03 & 0.48 & 0.022 & 1.34 & 75 \\
芦苇群落 & $0 \sim 20$ & 0.034 & 0.46 & 0.008 & 1.08 & 102 \\
& $20 \sim 80$ & 0.034 & 0.46 & 0.005 & 1.14 & 80 \\
& $80 \sim 800$ & 0.034 & 0.46 & 0.009 & 1.08 & 45 \\
\hline
\end{tabular}
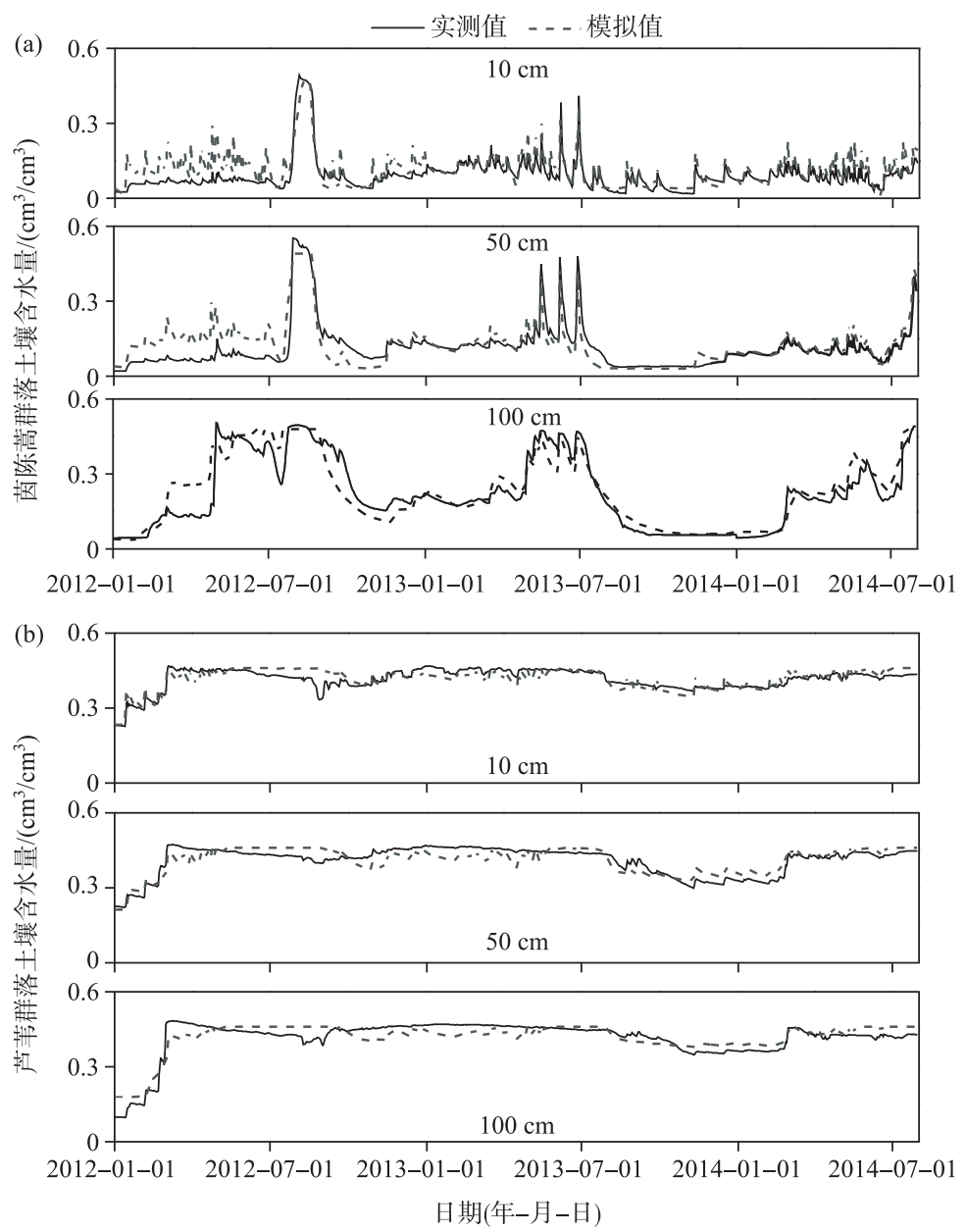

图 6 茵陈蒿 $(\mathrm{a})$ 和芦苇 $(\mathrm{b})$ 群落土壤含水量模拟值与实测值对比

Fig.6 Comparison of observed and simulated soil moisture in A. capillaris (a) and P. australis (b) communities 
表 3 茵陈蒿和芦苇群落土壤含水量模拟效果统计值

Tab.3 Assessment of observed and simulated soil water contents in A. capillaris and P. australis communities

\begin{tabular}{ccccccc}
\hline \multirow{2}{*}{ 植被群落 } & 深度 & \multicolumn{2}{c}{ 率定期 } & & \multicolumn{2}{c}{ 验证期 } \\
& & $R M S E /\left(\mathrm{cm}^{3} / \mathrm{cm}^{3}\right)$ & $R^{2}$ & & $R M S E /\left(\mathrm{cm}^{3} / \mathrm{cm}^{3}\right)$ & $R^{2}$ \\
\hline 茵陈蒿群落 & $10 \mathrm{~cm}$ & 0.04 & 0.83 & 0.03 & 0.72 \\
& $50 \mathrm{~cm}$ & 0.05 & 0.77 & 0.03 & 0.77 \\
& $100 \mathrm{~cm}$ & 0.07 & 0.76 & 0.02 & 0.92 \\
芦苇群落 & $10 \mathrm{~cm}$ & 0.03 & 0.67 & 0.02 & 0.81 \\
& $50 \mathrm{~cm}$ & 0.03 & 0.02 & 0.02 & 0.66 \\
\hline
\end{tabular}

\section{2 不同植被群落 GSPAC 系统界面水分运移规律分析}

3.2.1 大气一植物界面水分通量 大气一植物界面的水分通量为植物蒸腾. 茵陈蒿群落蒸腾量小于芦苇群落 蒸腾量, 年蒸腾总量分别为 346 470 mm (图 7a) 和 926 1057 mm(图 7b), 主要因为茵陈蒿群落的叶面积指 数和生境土壤含水量远小于芦苇群落. 植被蒸腾量存在显著的季节变化, 峰值均出现在植物生长旺季的 $7-$ 8 月,占年总量的 $40 \% \sim 46 \%$,植物衰亡期 12-2 月和萌发期 3 月的蒸腾量最小, 不足 $20 \mathrm{~mm} /$ 月.

3.2 .2 大气一土壤界面水分通量 大气一土壤界面的水分通量为土面蒸发和降水人渗. 研究区植被覆盖度较 高, 故土面蒸发量普遍较小, 茵陈蒿和芦苇群落的年土面蒸发量分别仅为 183 201 mm(图 7a) 和 144 177 $\mathrm{mm}$ (图 7b), 季节性差异不明显, 夏季 7-8 月蒸发量最大 ( $24 \sim 30 \mathrm{~mm} /$ 月), 冬季 12-2 月较小 ( 8 13 mm/ 月). 研究区湿地年降水量为 $1640 \sim 1746 \mathrm{~mm}$, 降水量扣除植物截留损失和少量地表产流后全部下渗, 年降水 人渗量为 $1570 \sim 1600 \mathrm{~mm}$, 雨季 4-6 月的降水人渗量 $(752 \sim 1110 \mathrm{~mm}$ ) 占年总量的 $60 \%$.

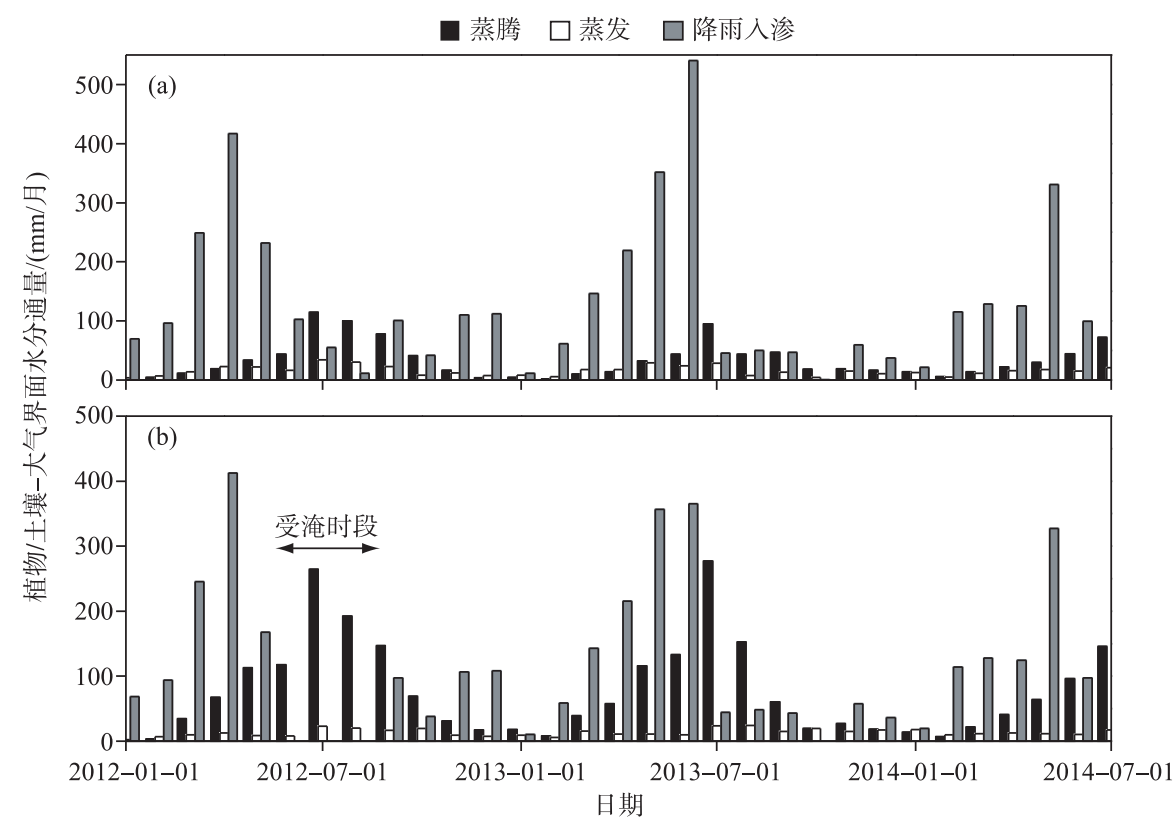

图 7 茵陈蒿 (a) 和芦苇 (b) 群落植物/土壤一大气界面水分通量月变化

Fig.7 Monthly variation of water fluxes across the vegetation/soil-atmosphere interfaces in A. capillaris (a) and P. australis (b) communities

3.2.3 根区土壤一地下水界面水分通量 根区土壤一地下水界面的水分通量为地下水向上补给和土壤水的深 层渗漏量. 地下水的向上运移主要发生在蒸散发作用强烈和地下水埋深较浅的时段 (图 8), 不同水文年补 
给量差异显著. 茵陈蒿群落地下水埋深较深(图 8c), 仅在汛期地下水浅埋时存在较大的向上补给通量 (图 $8 \mathrm{a}$ ）, 丰水年 2012 年最高地下水位可接近地表,地下水年向上补给量达 $513 \mathrm{~mm}$, 其中 $7-8$ 月份的补给总量 占 $86 \%$, 而枯水年 2013 年地下水向上补给通量基本为 0 . 芦苇群落地下水埋深较浅 ( 图 8c), 在蒸散旺季 7一 10 月和降水过后都有明显的向上补给通量(图 8b) , 丰水年 2012 年 (6-8 月芦苇群落淹水) 地下水年补给 量为 $277 \mathrm{~mm}$, 枯水年 2013 年芦苇群落 (未经历淹水) 地下水的年补给量为 $616 \mathrm{~mm}, 6-8$ 月的补给量占 $75 \%$. 茵陈蒿和芦苇群落根区土壤水分的年渗漏量分别为 $1110 \sim 1280 \mathrm{~mm}$ 和 $924 \sim 1053 \mathrm{~mm}$, 主要发生在鄱阳 湖雨季 4-6 月份, 占年渗漏量的 49\% 79\% (图 8 ).
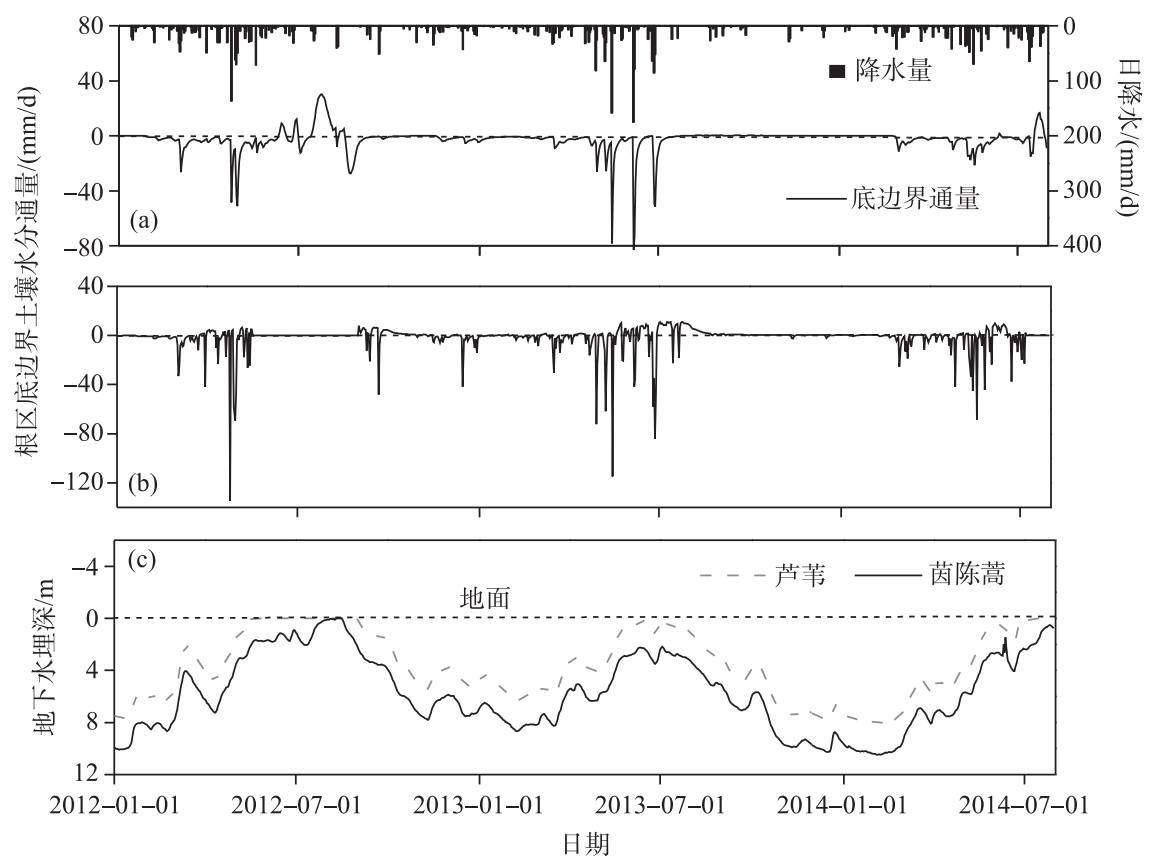

图 8 茵陈蒿 (a) 和芦苇 (b) 群落根区土壤底边界水分通量日变化及地下水埋深 $(\mathrm{c})$ (正值代表向上补给,负值代表深层渗漏)

Fig.8 Daily variation of water fluxes across the root zone bottom in A. capillaris (a) and $P$. australis (b) communities and groundwater depth (c)

\section{3 根系层土壤水量平衡分析}

根系层土壤水量平衡分析结果显示, 植被群落蒸腾用水存在 2 个明显不同的阶段: 生长初期 $(4-6$ 月) 和生长旺季 $(7-10$ 月).

植被的生长初期正值鄱阳湖的雨季, 茵陈蒿和芦苇群落的降水人渗量远大于植被蒸腾量, $T_{\mathrm{a}} / T_{\mathrm{p}}$ 为 $0.99 \sim$ 1.00 (表 4), 根区土壤水量平衡为盈余状态, 这表明此阶段植被群落生长用水不受水分限制, 大气降水可满 足植被的全部生长需水.

植被的生长旺季, 茵陈蒿和芦苇群落蒸腾总量显著增加, 然而此时鄱阳湖雨季结束, 降水人渗量减小至 不足 $200 \mathrm{~mm}$, 远小于植被蒸腾量, 根系层土壤水量平衡为亏损状态 (表 4), 这表明此阶段的降水量无法保证 植被生长的全部用水,植被还必须依赖其他水源, 如湖水、地下水和前期土壤水储量.

\section{4 不同水文年湿地水分来源及其对植被蒸腾用水的影响}

根据上述分析可知, 茵陈蒿和芦苇群落生长旺季 7-10月的蒸腾用水必须要依赖其他水源, 如湖水、地 下水和前期土壤水储量, 所以,进一步分析不同水文年湿地补给水分来源组成及其对植被蒸腾用水的影响.

3.4 .1 植被蒸腾 丰水年 2012 年 7-10月, 茵陈蒿和芦苇群落的 $T_{\mathrm{a}}$ 与 $T_{\mathrm{p}}$ 基本保持一致, $T_{\mathrm{a}}$ 占 $T_{\mathrm{p}}$ 的 $92 \%$ 以上 ( 图 9a、c), 说明丰水年生长旺季植被群落蒸腾用水不受水分亏缺的限制. 然而, 枯水年 2013 年 7- 10 月, 茵 
表 4 不同生长阶段植被群落根区水均衡要素比较分析

Tab.4 Water balance variables of root zone in different growth stages of different hydrological years

\begin{tabular}{cccccccccccc}
\hline 阶段 & 群落 & 水文年 & $T_{\mathrm{p}} / \mathrm{mm}$ & $T_{\mathrm{a}} / \mathrm{mm}$ & $E_{\mathrm{a}} / \mathrm{mm}$ & $R_{\mathrm{in}} / \mathrm{mm}$ & $L_{\mathrm{in}} / \mathrm{mm}$ & $G / \mathrm{mm}$ & $D / \mathrm{mm}$ & $\Delta W / \mathrm{mm}$ & $T_{\mathrm{a}} / T_{\mathrm{p}}$ \\
\hline 生长初期 & \multirow{2}{*}{ 茵陈蒿 } & 丰水年 & 96 & 96 & 61 & 752 & 0 & 74 & 557 & 107 & 0.99 \\
$4-6$ 月 & & 枯水年 & 90 & 90 & 73 & 1110 & 0 & 0 & 877 & 66 & 1.00 \\
& \multirow{2}{*}{ 芦苇 } & 丰水年 & 298 & 298 & 30 & 510 & 193 & 97 & 457 & 16 & 1.00 \\
& & 枯水年 & 307 & 307 & 31 & 937 & 0 & 182 & 762 & 15 & 0.99 \\
生长旺季 & \multirow{2}{*}{ 4-茵陈蒿 } & 丰水年 & 349 & 334 & 96 & 209 & 0 & 439 & 375 & -161 & 0.96 \\
& \multirow{2}{*}{ 月 } & 枯水年 & 367 & 203 & 54 & 143 & 0 & 13 & 51 & -154 & 0.55 \\
& \multirow{2}{*}{ 芦苇 } & 丰水年 & 735 & 677 & 82 & 136 & 491 & 164 & 87 & -50 & 0.92 \\
& & 枯水年 & 943 & 510 & 89 & 137 & 0.0 & 401 & 39 & -95 & 0.54 \\
\hline
\end{tabular}

陈蒿和芦苇群落的 $T_{\mathrm{a}}$ 过程线远低于 $T_{\mathrm{p}}$ 过程线, $T_{\mathrm{a}}$ 仅占 $T_{\mathrm{p}}$ 的约 $55 \%$ (图 $9 \mathrm{~b} 、 \mathrm{~d}$ ), 表明枯水年生长旺季没有充足 的水分来保证植物根系的潜在吸水 (参见公式 4), 茵陈蒿和芦苇群落遭受严重的水分胁迫. 此外, 植被 $T_{\mathrm{a}}$ / $T_{\mathrm{p}}$ 的变化显示, 水位的降低导致湿地植物茵陈蒿和芦苇群落在 7-10 月遭受水分胁迫的程度更严重、历时 更长(图 10).
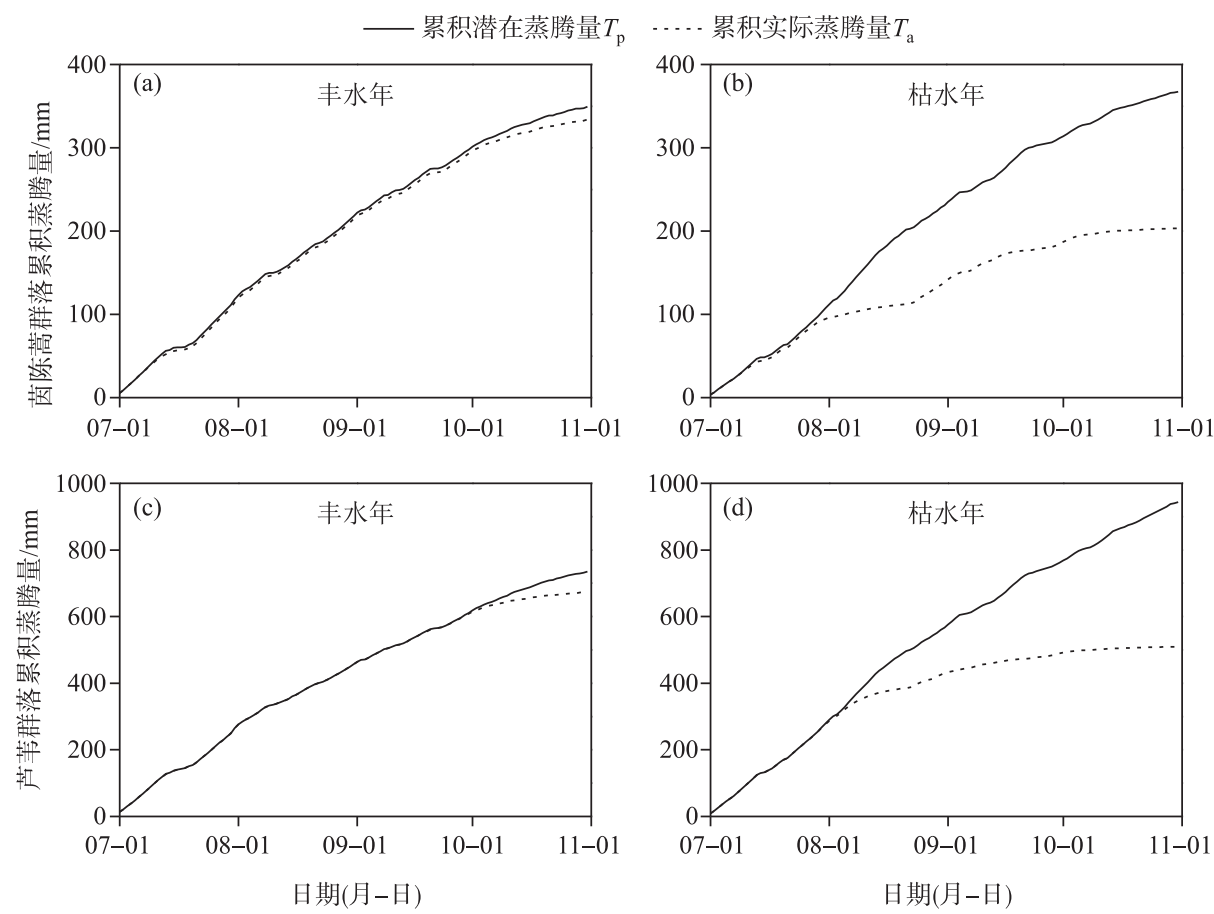

图 9 不同水文年茵陈蒿 $(a, b)$ 和芦苇 $(c 、 d)$ 群落生长旺季累积蒸腾量过程线

Fig.9 Cumulative transpiration of $A$. capillaris ( $\mathrm{a}, \mathrm{b}$ ) and P. australis (c, d) communities in the main growth stage of different hydrological years

3.4.2 补给水源组成及贡献 生长旺季湿地植被蒸腾用水的差异主要因为补给水源贡献不同. 丰水年生长 旺季, 茵陈谷群落以地下水补给为主, 占总补给量的 55\%, 降水和前期土壤水储量分别占 26\%和 19\%（图 11a). 然而, 枯水年生长旺季地下水的补给比例下降至仅 4\%, 降水和前期土壤水储量成为主要水源, 分别占 $47 \%$ 和 $49 \%$ (图 11b), 但是此时实际蒸腾用水仅约为潜在蒸腾用水的一半 ( $55 \%$ ). 这说明地下水的补给贡 献量是决定茵陈高群落生长旺季是否遭受水分胁迫的关键因素, 枯水年仅靠降水和土壤水储量难以保证茵 

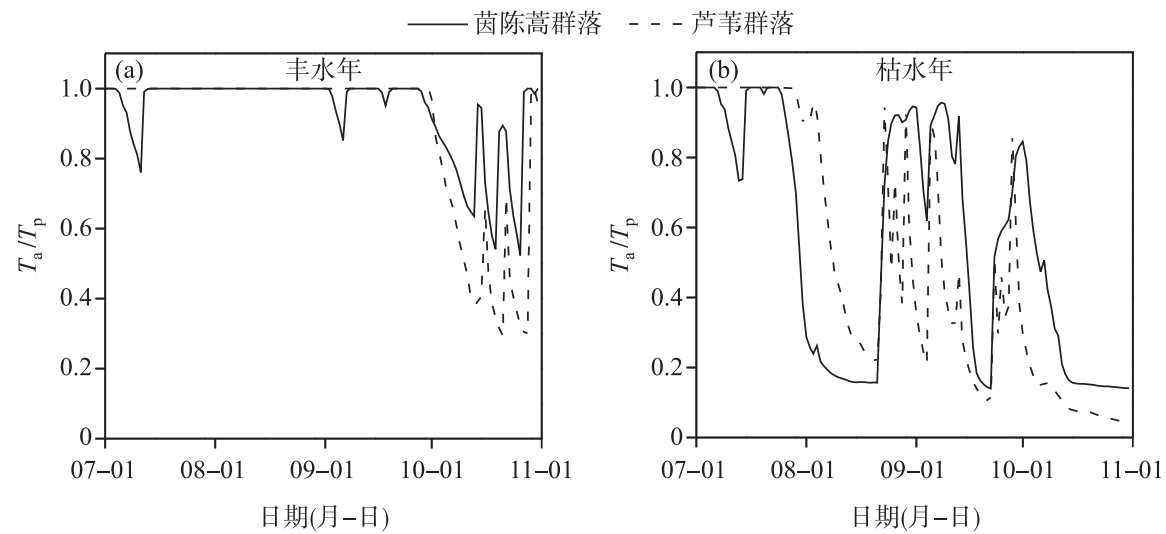

图 10 茵陈蒿 $(\mathrm{a})$ 和芦苇 $(\mathrm{b})$ 群落生长旺季水分胁迫指数 $\left(T_{\mathrm{a}} / T_{\mathrm{p}}\right)$ 变化

Fig.10 Variation of water stress index $T_{\mathrm{a}} / T_{\mathrm{p}}$ ratio in A. capillaris (a) and P. australis (b) communities

陈蒿群落的用水充足.

芦苇群落丰水年湖水和地下水分别占总补给水量的 58\% 和 $20 \%$ (图 11c), 两者最大能提供芦苇蒸腾 $97 \%$ 的水分消耗 (表 4). 然而, 枯水年生长旺季芦苇群落以地下水补给为主 (未淹水), 占总补给量的 $61 \%$ (图 11d), 最大能提供植被蒸腾用水总量的 79\% (表 4). 这表明芦苇群落的植被蒸腾用水绝大部分来自湖 水和地下水, 它们对根区土壤的补给通量直接决定了芦苇群落遭受干旱胁迫的程度和植被蒸腾的用水量, 而且枯水年仅依靠地下水无法满足芦苇群落旺季的全部蒸腾需水.

(a)

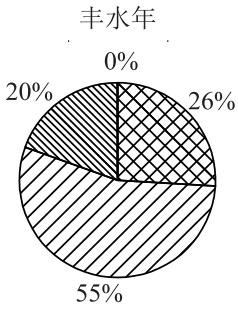

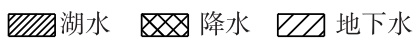

(b)

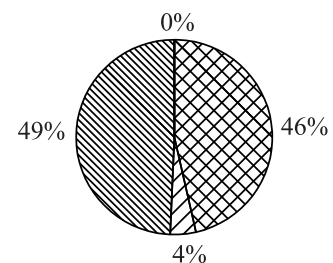

(c)

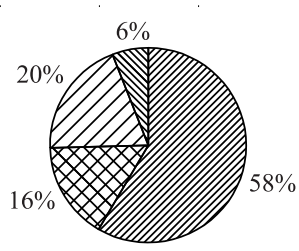

(d)

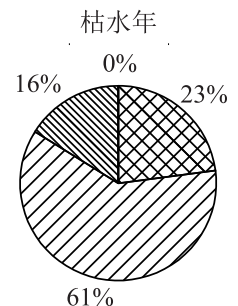

图 112012 和 2013 年生长旺季茵陈蒿 $(a, b)$ 和芦苇 $(c 、 d)$ 群落水分来源贡献比例

Fig.11 Water sources contribution in main growth stage in A. capillaris ( $\mathrm{a}, \mathrm{b}$ ) and P. australis (c, d) communities in 2012 and 2013

\section{4 讨论}

湿地生态水文环境复杂, 数据监测和获取困难, 数值模型模拟已经成为研究湿地水分运移的重要手段 之一 ${ }^{[44]}$. HYDRUS-1D 模型是一款用于模拟饱和一非饱和介质水热传输的模型 ${ }^{[28]}$, 以往研究多用于农田生 态系统, 近年来, 一些学者成功将其应用于天然湿地的水分动态模拟, 如黄河三角洲湿地、三江平原湿地、黑

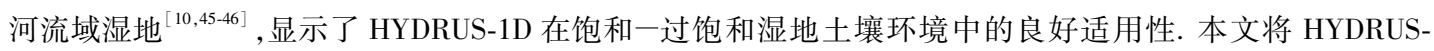
$1 \mathrm{D}$ 应用于季节性淹水的湖泊湿地生态系统, 淹水时期地表被湖水覆盖, 给定为压力水头边界, 代表湖水人 渗补给条件下的模拟,虽然此时土体完全饱和,垂向土壤水分运动模拟不具有明显的实际意义,但是模拟的 蒸散发消耗水量全部来自湖水, 不影响土壤的水量平衡, 这在理论上与实际状况基本相符. 事实上, 为了保 证模拟过程的连续性, 完整再现湿地季节性干湿交替变化, 模型上边界必须要采用动边界条件, 考虑到季节 性淹水湿地与滨海沼泽湿地的相似性, 本文借鉴了间歇性淹水的潮汐沼泽湿地水文过程模拟的边界处理方 
式 ${ }^{[47-48]}$, 在地表出露时采用通量边界, 在淹水时采用水头边界, 使模型最大程度地与实际情况吻合. 本文这 种处理方式可为类似区域的研究提供参考.

此外, 本文在缺乏水分通量监测数据的前提下, 仅通过土壤含水率验证模型并得到较好的模拟效果, 但 通过比较年蒸散量的模拟值与波文比能量平衡法估算值以及文献报道值, 间接验证了土壤/植被一大气界面 的水分通量. 研究区茵陈蒿群落波文比能量平衡法 (BREB) 估算的蒸散量与模拟的蒸散量变化趋势基本一 致, 量值接近, 只在土壤极端干旱时段有较大偏差 (图 12); 另外, 茵陈蒿群落的年蒸散量为 $554 \sim 671 \mathrm{~mm}$, 略 低于鄱阳湖流域年蒸散量 $(600 \sim 840 \mathrm{~mm})^{[49-50]}$, 主要原因是茵陈蒿群落属于中生性草甸, 植被覆盖度低于流 域的森林下垫面,而且生境较低的土壤水分含量限制了蒸散的水分供应; 芦苇群落的年蒸散量为 1100 $1210 \mathrm{~mm}$, 与鄱阳湖水面蒸发量 $(1024 \sim 1218 \mathrm{~mm})$ 相差不大 ${ }^{[51-52]}$, 这些都从侧面证明了本文模型的可靠性. 但 必须承认, 目前还缺少对地下水一土壤界面的补给量等方面的直接验证, 而且由于模型结构和参数估计的不 确定性, 生态水文模型模拟结果本身具有一定的不确定性, 这些都会导致计算的水源贡献产生一定误差. 今 后工作中, 我们将结合蒸渗仪观测和同位素技术获取更长序列的生态水文数据, 以此来进一步提高模型的 准确性和模拟结果的精度, 回答不同植物的水分竞争利用问题.

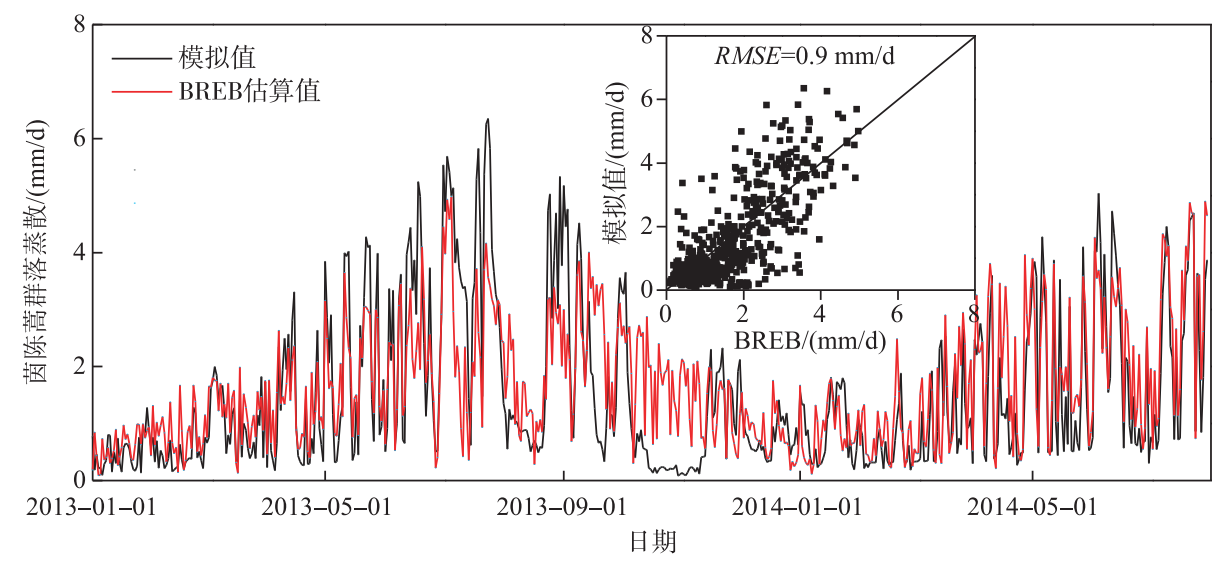

图 12 茵陈蒿群落蒸散发模拟值与波文比能量平衡法计算值对比

Fig.12 Comparison of simulated evapotranspiration and evapotranspiration estimated by BREB in the A. capillaris community

“干一湿”交替的季节性洪泛湿地, 水位波动使湿地在“水生”与“陆生”生境间交替变化,在湿地出露期, 地下水在蒸腾拉力和毛细作用下不断向上补给根区土壤水分 ${ }^{[9-10]}$. 本研究发现, 鄱阳湖湿地根系层底部土壤 水分交换频繁, 丰水年茵陈蒿群落生长旺季地下水对根区土壤的补给量占总补给量的 $55 \%$, 枯水年芦苇群 落生长旺季地下水的补给比例为 $61 \%$ (表 4). 地下水补给量直接影响鄱阳湖湿地植物的蒸腾耗水, 丰水年 植被蒸腾用水充足, 干旱胁迫主要出现在枯水年的 8-10月 (图 9), 这说明湿地植被不仅需要抵御淹水造成 的缺氧胁迫, 还可能在出露时期遭受不同程度的干旱胁迫 ${ }^{[33-55]}$. 事实上, 研究表明植物在耐旱和耐淹之间存 在一个权衡, 湿地植物在长期的适应进化过程中, 通过发育大量的通气组织和特殊的形态学特征而具备了 较高的淹水耐受性, 而干旱耐受性往往较差 ${ }^{[8,55-56]}$. 那么显然, 在水位波动幅度较大的洪泛湿地, 干旱胁迫已 然成为植被面临的又一生存压力,干旱导致的不同生态型植物种间水分竞争值得继续研究.

2000 年以来, 鄱阳湖干旱事件频发, “秋旱” 问题引起了学者和媒体的广泛关注 ${ }^{[57-58]}$, 本研究发现, 枯水 年 8-10 月鄱阳湖湿地高位滩地植被会遭受严重的水分胁迫,这或许是近年来鄱阳湖湿地植被出现明显矮 化、旱化以及分布面积萎缩的内在原因之一. 如果未来鄱阳湖干旱将加剧 ${ }^{[15,21]}$, 水位的下降会进一步减少高 位滩地的补给水量, 导致高位滩地植被遭受缺水胁迫的程度加剧、历时延长, 最终, 中生、旱生植物可能在种 群竞争中占有优势, 高位滩地植被群落的分布高程向下迁移, 从而促进湿地植被的正向演替. 当然, 湿地生 态水文过程的影响因素和作用机理复杂, 植被生长和分布是气候、地形、水文、土壤等众多影响因子长期作 
用的结果 ${ }^{[47,59]}$. 在区域尺度上, 气候通过对降水和气温的分配而成为影响植被生长的关键因素 ${ }^{[60]}$; 在景观 尺度上,地形和水文条件直接决定植被分布格局的差异 ${ }^{[61]}$; 在群落或种群尺度上,土壤属性和种间关系可能 是影响湿地植被生长、繁殖的主要因素 ${ }^{[62-63]}$. 因此, 湿地生态水文作用研究要充分考虑环境要素的空间异质 性. 本文主要针对群落尺度的植被生长用水规律与水源组成开展研究, 研究结果可为鄱阳湖北部湖区高位 滩地植被种间竞争研究提供理论参考, 考虑到鄱阳湖湿地南北地形差异, 同一植被群落在不同湖区的分布 高程有一定位移,如何将点尺度的研究结果扩展到空间尺度仍然是未来研究的重点和难点.

\section{5 结论}

本文选取鄱阳湖洲滩湿地高位滩地的 2 种典型植被: 茵陈蒿和芦苇群落, 构建了 HYDRUS-1D 水分运移 模型, 模拟分析了不同植被群落地下水一土壤一植被一大气系统 (GSPAC) 界面水分通量, 阐明了丰水年 (2012 年) 和枯水年 (2013 年) 条件下, 鄱阳湖湿地植被群落的蒸腾用水规律和水源构成, 主要得出以下 结论:

1) 湿地 GSPAC 系统界面水分通量季节变化显著. 茵陈蒿和芦苇群落土壤一大气界面的年蒸发量为 144 $201 \mathrm{~mm}$, 年降水人渗量 1570 1600 mm, 主要集中在 4-6 月, 占总量的 $60 \%$; 植被一大气界面的年蒸腾量分 别为 346 470 $\mathrm{mm}$ 和 $926 \sim 1057 \mathrm{~mm}$, 其中 7-8 月蒸腾量最大, 占总量的 40\% 46\% ; 地下水一根区土壤界面 的向上补给水量受水位变化的影响显著, 地下水年补给量分别为 $15 \sim 513 \mathrm{~mm}$ 和 $277 \sim 616 \mathrm{~mm}$, 主要集中在 地下水埋深较浅和蒸腾旺盛的阶段, 水分渗漏量分别为 $1110 \sim 1280 \mathrm{~mm}$ 和 $924 \sim 1053 \mathrm{~mm}$, 集中在 4-6月, 占 $49 \% \sim 79 \%$.

2) 受湿地水分补给通量季节变化的影响,湿地植被不同生长阶段的蒸腾用水规律不同. 生长初期 (4-6 月), 降水人渗量可满足全部的植被蒸腾用水, 植被实际蒸腾量等于潜在蒸腾量; 夏秋生长旺季期 ( $7-10$ 月) 的植被蒸腾用水主要受湖水和地下水补给量的影响, 不同水文年差异较大, 丰水年植被蒸腾用水充足, 枯水年植被遭受严重水分胁迫,实际蒸腾量仅为潜在蒸腾量的 $55 \%$.

3 ) 不同水文年水位变化导致生长旺季湿地植物的水源组成不同. 茵陈蒿群落丰水年以地下水补给为 主, 占水源总量的 55\%, 枯水年以降水和前期土壤水储量为主, 分别占 $46 \%$ 和 $49 \%$; 芦苇群落丰水年以湖水 和地下水补给为主,分别占水源总量的 $58 \%$ 和 $20 \%$,枯水年以地下水补给为主, 占 $61 \%$.

\section{6 参考文献}

[ 1 ] Cui BS, Yang ZF eds. Wetland science. Beijing: Beijing Normal University Press, 2006: 45-55. [崔保山, 杨志峰. 湿地 学. 北京: 北京师范大学出版社, 2006: 45-55]

[ 2 ] Zhang GX, Yin XR, Feng XQ. Review of the issues related to wetland hydrology research. Wetland Science, 2008, 6(2): 105-115. [章光新, 尹雄锐, 冯夏清. 湿地水文研究的若干热点问题. 湿地科学, 2008, 6(2): 105-115.]

[ 3 ] Deng W, Pan XL, Luan ZQ. Research progress of wetland hydrology. Advances in Water Science, 2003, 14(4) : 521-527. [邓伟, 潘响亮, 奕兆擎. 湿地水文学研究进展. 水科学进展, 2003, 14(4): 521-527.]

[ 4 ] Liu CM. Study of interface processes of water cycle in soil-plant-atmosphere continuum. Acta Geographica Sinica, $1997, \mathbf{5 2}$ (4)：80-87. [刘昌明. 土壤-植物-大气系统水分运行的界面过程研究. 地理学报, 1997, 52(4) : 80-87.]

[ 5 ] Cooper DJ, Sanderson JS, Stannard DI et al. Effects of long-term water table drawdown on evapotranspiration and vegetation in an arid region phreatophyte community. Journal of Hydrology, 2006, 325(1/2/3/4) : 21-34.

[6] Guo YD. Influence of Deyeuxia angustifolia vegetation on the evapotranspiration of mire in the Sanjiang Plain. Wetland Science, 2008, 6(3) : 392-397. [ 郭跃东. 毛苔草植被对沼泽湿地蒸散发影响的试验研究. 湿地科学, 2008, 6(3): 392-397.]

[ 7 ] Sun L, Song CC. Studies of the energy balance and evapotranspiration over the typical marsh wetland in Sanjiang plain. Advances in Water Science, 2008, 19(1): 43-48. [孙丽, 宋长春. 三江平原典型沼泽湿地能量平衡和蒸散发研究. 水科 学进展, 2008, 19(1): 43-48.]

[ 8 ] Luo WB, Xie YH, Song FB. Survival strategies of wetland plants in flooding environments. Chinese Journal of Ecology, 2007, 26(9) : 1478-1485. [罗文泊, 谢永宏, 宋凤斌. 洪水条件下湿地植物的生存策略. 生态学杂志, 2007,26 (9) : 1478-1485.] 
[ 9 ] Pagter M, Bragato C, Brix H. Tolerance and physiological responses of Phragmites australis to water deficit. Aquatic Botany, $2005,25(3): 520-530$.

[10] Xie T, Liu XH, Sun T. The effects of groundwater table and flood irrigation strategies on soil water and salt dynamics and reed water use in the Yellow River Delta, China. Ecological Modeling, 2011, 222(2) : 241-252.

[11] Ge G, Zhao AN, Zhong YY et al. Patterns of dominant populations of plants in islets of Poyang Lake. Wetland Science, 2011，9(1): 19-25. [葛刚, 赵安娜, 钟义勇等. 鄱阳湖洲滩优势植物种群的分布格局. 湿地科学, 2011, 9(1): 19-25.]

[12] Liu XZ, Ye JX eds. Jiangxi wetland. Beijing: China Forestry Press. 2000: 184-217. [刘信中, 叶居新. 江西湿地. 北 京: 中国林业出版社, 2000: 184-217.]

[13] Min Q, Zhan LS. Characteristics of low-water level changes in Lake Poyang during 1952 -2011. J Lake Sci, 2012, 24( 5) : 675-678. DOI: 10.18307/2012.0505. [闵骞, 占腊生. 1952-2011 年鄱阳湖枯水变化分析. 湖泊科学, 2012, 24(5): 675-678. ]

[14] Liu YB, Zhao XS, Wu GP. A primary investigation on the formation of frequent droughts in the Poyang Lake basin in recent decade. Resources and Environment in the Yangtze, 2014, 23(1): 131-138. [刘元波, 赵晓松, 吴桂平. 近十年鄱 阳湖区极端干旱事件频发现象成因初析. 长江流域资源与环境, 2014, 23(1): 131-138.]

[15] Zhang Q, Ye XC, Werner AD et al. An investigation of enhanced recessions in Poyang Lake: Comparison of Yangtze River and local catchment impacts. Journal of Hydrology, 2014, 517: 425-434.

[16] Zhou WB, Wan JB, Jiang JH et al eds. Water level changes of Poyang Lake and Yangtze River and their effects on the ecosystem. Beijing: Science Press, 2011: 73-81. [周文斌, 万金保, 姜加虎等. 鄱阳湖江湖水位变化对其生态系统影 响. 北京: 科学出版社, 2011: 73-81.]

[17] Hu ZP, Ge G, Liu CL et al. Study on the structure of Lake Poyang wetland plant ecosystem and influence of water level on it. Resources and Environment in the Yangtze, 2010, 19(6) : 597-605. [胡振鹏, 葛刚, 刘成林等. 鄱阳湖湿地植物生 态系统结构及湖水位对其影响研究. 长江流域资源与环境, 2010，19(6) : 597-605.]

[18] Yu L, He LH, Zhang Q et al. Effects of the Three Gorges Project on the typical wetland vegetations of Poyang Lake. Geographical Research, 2011, 30(1)：134-144. [余莉, 何隆华, 张奇等. 三峡工程蓄水运行对鄱阳湖典型湿地植被的 影响. 地理研究, 2011, 30(1): 134-144.]

[19] Han X, Chen X, Feng L. Four decades of winter wetland changes in Poyang Lake based on Landsat observations between 1973 and 2013. Remote Sensing of Environment, 2015, 156: 426-437.

[20] Li YL, Zhang Q, Yao J et al. Integrated simulation of hydrological and hydrodynamic processes for Lake Poyang catchment system. J Lake Sci, 2013, 25(2) : 227-235. DOI: 10.18307/2013.0208. [李云良, 张奇, 姚静等. 鄱阳湖湖泊流域系 统水文水动力联合模拟. 湖泊科学, 2013, 25(2): 227-235.]

[21] Ye XC, Zhang Q, Bai L et al. A modeling study of catchment discharge to Poyang Lake under future climate in China. Quaternary International, 2011, 244 (2) : 221-229.

[22] Zhang LL, Yin JX, Jiang YZ et al. Relationship between wetland vegetation community and hydrological regime in Lake Poyang nature reserve. Advances in Water Science, 2012, 23(6) : 768-776. [张丽丽, 殷峻暹, 蒋云钟等. 鄱阳湖自然 保护区湿地植被群落与水文情势关系. 水科学进展, 2012, 23(6): 769-776. ]

[23] Xu XL, Zhang Q, Tan ZQ et al. Effects of water-table depth and soil moisture on plant biomass, diversity, and distribution at a seasonally flooded wetland of Poyang Lake, China. Chinese Geographical Science, 2015, 25(4) : 739-756.

[24] Zhang QJ, Yu XB, Qian JX et al. Distribution characteristics of plant communities and soft organic matter and main nutrients in the Poyang Lake Nanji Wetland. Acta Ecologica Sinica, 2012, 32(12) : 3656-3669. [张全军, 于秀波, 钱建金金 等. 鄱阳湖南矶湿地优势植物群落及土壤有机质和营养元素分布特征. 生态学报, 2012, 32(12): 3656-3669.]

[25] Qin XY, Li F, Chen XS et al. Growth responses and non-structural carbohydrates in three wetland macrophyte species following submergence and de-submergence. Acta Physiologiae Plantarum, 2013, 35(7) : 2069-2074.

[26] Feng WJ, Xu LG, Wang XL et al. Response of Carex cinerascens populations to groundwater level gradients in the Poyang Lake wetland. Acta Ecological Sinica, 2016, 36(16) : 5109-5115. [冯文娟, 徐立刚, 王晓龙等. 鄱阳湖洲滩湿地地下 水位对灰化䔔草种群的影响. 生态学报, 2016, 36(16): 5109-5115.]

[27] Lin H, Xu XL, Zhang Q. Relationship of the water supply and drainage in a typical wetland of Lake Poyang. J Lake Sci, 2017, 29(1) : 160-175. DOI: 10.18307/2017.0118. [林欢, 许秀丽, 张奇. 鄱阳湖典型洲滩湿地水分补排关系. 湖 
泊科学, $2017,29(1): 160-175$.]

[28] Šimůnek J, van Genuchten MTH, Šejna M. The HYDRUS-1D software package for simulating the movement of water, heat, and multiple solutes in variably saturated media, Version 4.0. California, USA: Department of Environmental Sciences, University of California, 2008.

[29] Jimenez-Martinez J, Skaggs TH, van Genuchten MT et al. A root zone modelling approach to estimating groundwater recharge from irrigated areas. Journal of Hydrology, 2009, 367 (1/2) : 138-149.

[30] Min Q, Min D. Drought change characteristics and drought protection countermeasures for Poyanghu Lake Basin. Journal of China Hydrology, 2010, 30 (1) : 84-88. [闵骞, 闵聑. 鄱阳湖区干旱演变特征与水文防旱对策. 水文, 2010,30 (1) : 84-88.]

[31] Cai HS, Zhao XM, Zhu DH. Discussion on Poyang Lake wetland and its sustainable management. Yangtze River, 2007,38 (2) : 73-76. [ 蔡海生, 赵小敏, 朱德海. 鄱阳湖湿地整理与可持续管理探讨. 人民长江, 2007, 38(2) : 73-76.]

[32] Yu L, He LH, Zhang Q et al. Landsat-TM data based study on dynamic changes of the typical wetlands of Poyang Lake. Remote Sensing Information, 2010, 6: 48-54. [余莉, 何隆华, 张奇等. 基于 Landsat-TM 影像的鄱阳湖典型湿地动态 变化研究. 遥感信息, $2010,6: 48-54$.

[33] Ye MY. Assessing on the ecological environment vulnerability of Poyang Laketypical wetland [Dissertation]. Nanchang: Jiangxi Normal University, 2006. [ 叶慕亚. 鄱阳湖典型湿地生态环境脆弱性评估 [ 学位论文]. 南昌: 江西师范大 学, 2006]

[34] Xu XL, Zhang Q, Li YL et al. Inner-annual variation of soil water content and groundwater level in a typical islet wetland of Lake Poyang. J Lake Sci, 2014, 26(2) : 260-268. DOI: 10.18307/2014.0213. [许秀丽, 张奇, 李云良等. 鄱阳湖 典型洲滩湿地土壤含水量和地下水位年内变化特征. 湖泊科学, 2014, 26(2): 260-268.]

[35] Li YL, Xu XL, Zhao GZ et al. Research of soil textures and soil-water characteristic parameters in a typical wetland of Poyang Lake. Resources and Environment in the Yangtze Basin, 2016, 25(8): 1-9. [李云良, 许秀丽, 赵贵章等. 鄱阳 湖典型洲滩湿地土壤质地与水分特征参数研究. 长江流域资源与环境, 2016, 25(8): 1-9.]

[36] Skaggs TH, Shouse PJ, Poss JA. Irrigating forage crops with saline waters: 2. Modeling root uptake and drainage. Vadose Zone Journal, 2006, 5(3) : 824-837.

[37] van Genuchten MTh. A numerical model for water and solute movement in and below the root zone. Unpublished Research Report, U.S. Salinity laboratory, USDA, ARS, Riverside, California, 1987.

[38 ] Allen R, Pereira LS, Raes D et al. Crop evapotranspiration: guidelines for computing crop water requirements, FAO Irrigation and Drainage Paper 56. Rome: Food and Agriculture Organization of the United Nations, 1998.

[39] Ritchie JT. Model for predicting evaporation from a row crop with incomplete cover. Water Resource Research, 1972, 8( 5) : 1204-1213.

[40] Jarvis NJ. Simple empirical model of root water uptake. Journal of Hydrology, 1989, 107(1/2/3/4) : 57-72.

[41] Zhu YH, Ren LL, Skaggs TH et al. Simulation of Populus euphratica root uptake of groundwater in an arid woodland of the Ejina Basin, China. Hydrology Process, 2009, 23(17) : 2460-2469.

[42] Shao MA, Wang QJ, Huang MB eds. Soil physics. Beijing: Higher Education Press, 2006: 22-23. [邵明安, 王全九, 黄 明斌. 土壤物理学. 北京: 高等教育出版社, 2006: 22-23.]

[43] Gao HY, Yang LH. Analysis of parameters on soil water characteristic curves of different soil texture. Journal of Agricultural University of Hebei, 2012, 35(5): 129-132. [高惠嫣, 杨路华. 不同质地土壤的水分特征曲线参数分析. 河北农 业大学学报, 2012, 35(5): 129-132.]

[44] Wang YL, Wang X, Sun T. Wetland eco-hydrological models: A review. Chinese Journal of Ecology. 2008, 27 ( 10) : 1753-1762. [王育礼, 王烜, 孙涛. 湿地生态水文模型研究进展. 生态学杂志, 2008, 27(10) : 1753-1762.]

[45] Li SH, Zhou DM, Luan ZQ et al. Quantitative simulation on soil moisture contents of two typical vegetation communities in Sanjiang Plain, China. Chinese Geographical Science, 2011, 21(6) : 723-733.

[46] Li HJ, Yi J, Zhang JG et al. Modeling of soil water and salt dynamics and its effects on root water uptake in Heihe Arid wetland, Gansu, China. Water, 2015, 7: 2382-2401.

[47] Xin P, Kong J, Li L et al. Modelling of groundwater-vegetation interactions in a tidal marsh. Advances in Water Resources, 2013, 57: 52-68.

[48] Xia YQ, Li HL, Boufadel MC et al. Hydrodynamic factors affecting the persistence of the Exxon Valdez oil in a shallow 
bedrock beach. Water Resources Research, 2010, 46: W10528. DOI: 10.1029/2010WR009179.

[49] Liu J, Zhang Q, Xu CY et al. Change of actual evapotranspiration of Poyang Lake watershed and associated influencing factors in the past 50 years. Resources and Environment in the Yangtze Basin, 2010, 19(2): 139-145. [刘健, 张奇, 许 崇育等. 近 50 年鄱阳湖流域实际蒸发量的变化及影响因素. 长江流域资源与环境, 2010, 19(2): 139-145.]

[50] Wu GP, Liu YB, Zhao XS. Spatio-temporal variations of evapotranspiration in Poyang Lake Basin using MOD16 products. Geographical Research, 2013, 32(4): 617-627. [ 吴桂平, 刘元波, 赵晓松. 基于 MOD16 产品的鄱阳湖流域地表蒸 散量时空分布特征. 地理研究, 2013, 32(4): 617-627.]

[51] Min Q, Liu Y. Calculation of lake evaporation and trend analysis of Lake Poyang: 1955-2004. J Lake Sci, 2006, 18 (5): 452-457. DOI: 10.18307/2006.0502. [闵骞, 刘影. 鄱阳湖水面蒸发量的计算与变化趋势分析 (1955-2004). 湖泊 科学, $2006,18(5)$ : 452-457.]

[52] Min Q, Su ZP, Wang XJ. Characteristics and causes of Poyang Lake Surface evaporation variation in recent 50 years. Meteorology and Disaster Reduction Research, 2007, 30(3) : 17-20. [闵骞, 苏宗萍, 王叙军. 近 50 年鄱阳湖水面蒸发变 化特征及原因分析. 气象与减灾研究, 2007, 30(3) : 17-20.]

[53] Sommer R, Folster H, Vielhauer K et al. Deep soil water dynamics and depletion by secondary vegetation in the eastern Amazon. Soil Science Society of America Journal, 2003, 67(6) : 1672-1686.

[54] Hammersmark CT, Rains MC, Wickland AC et al. Vegetation and water-table relationships in a hydrologically restored riparian meadow. Wetlands, 2009, 29(3) : 785-797.

[55] Li F, Qin XY, Xie YH et al. Physiological mechanisms for plant distribution pattern: responses to flooding and drought in three wetlands from Dongting Lake, China. Limnology, 2013, 14(1): 71-76.

[56] Luo WB, Song FB, Xie YH. Trade-off between tolerance to drought and tolerance to flooding in three wetland plants. Wetlands, 2008, 28(3) : 866-873.

[57] Zhang Q, Li L, Wang YG et al. Has the Three-Gorges Dam made the Poyang Lake wetlands wetter and drier? Geophysical Research Letters, 2012, 39: L20402.

[58] Lu XX, Yang XK, Li SY. Dam not sole cause of Chinese drought. Nature, 2011, 475(7355) : 174.

[59] LI X, Xie YH, Huang JS et al. Research progresses on the formation mechanism of vegetation distribution pattern in wetlands. Wetland Science, 2009, 7(3) : 280-284. [李旭, 谢永宏, 黄继山等. 湿地植被格局成因研究进展. 湿地科学, 2009, 7(3): 280-284.]

[60] Mortsch LD. Assessing the impact of climate change on the Great Lakes shoreline wetlands. Climatic Change, 1998,40 (2) : 391-416. DOI: $10.1023 / \mathrm{A}: 1005445709728$.

[61] Catherine OK. Vegetation patterns resulting from spatial and temporal variability in hydrology, soils, and trampling in an isolated basin marsh, New Hampshire, USA. Wetlands, 2005, 25(2) : 239-251.

[62] Moser KF, Ahn C, Noe GB. The influence of microtopography on soil nutrients in created mitigation wetlands. Restoration Ecology, 2009, 17(5): 641-651. DOI: 10.1111/j.1526-100X.

[63] Chui TFM, Low SY, Liong SY. An ecohydrological model for studying groundwater-vegetation interactions in wetlands. Journal of Hydrology, 2011, 409(1/2) : 291-304. 